\title{
Production of Flowers of Ornamental Sunflower Irrigated With Wastewater From Fish Culture
}

\author{
Lunara G. da S. Rêgo ${ }^{1}$, Neyton de O. Miranda ${ }^{2}$, Kaline D. Travassos ${ }^{2,3}$, Nildo da S. Dias ${ }^{2}$, Rutilene R. da Cunha ${ }^{1}$, \\ Maria E. da Cunha ${ }^{1}$, Francisco C. G. Santana ${ }^{4}$, Poliana M. da C. Bandeira ${ }^{4} \&$ Francisco X. de Oliveira Filho ${ }^{5}$ \\ ${ }^{1}$ Graduate Program in Soil and Water Management, Federal Rural University of the Semiarid, Mossoró, Brazil \\ ${ }^{2}$ Center of Agrarian Sciences, Federal Rural University of the Semiarid, Mossoró, Brazil \\ ${ }^{3}$ Coordination for the Improvement of Higher Level Education Personnel, Brasília, Brazil \\ ${ }^{4}$ Federal Rural University of the Semiarid, Mossoró, Brazil \\ ${ }^{5}$ Center of Engeneering, Federal Rural University of the Semiarid, Mossoró, Brazil \\ Correspondence: Neyton de O. Miranda, Centro de Ciências Agrárias, Universidade Federal Rural do \\ Semi-Árido, R. Francisco Mota, 572-Pres. Costa e Silva, Mossoró, RN, 59625-900, Brazil. Tel: \\ 55-84-99411-1007. E-mail: neyton@ufersa.edu.br
}

\begin{tabular}{|c|c|c|}
\hline Received: August 31, 2018 & Accepted: October 10, 2018 & Online Published: December 15, 2018 \\
\hline oi:10.5539/jas.v1 1 n 1 p130 & URL: https://doi.org/10. &.$v 11 n 1 p 130$ \\
\hline
\end{tabular}

The research was financed in part by the Coordenação de Aperfeiçoamento de Pessoal de Nivel Superior-Brasil (CAPES)_Finance Code 001.

\begin{abstract}
The unregulated use and increased demand in face of the demographic and economic growth of society caused reduction in the availability of water resources in quantity and quality. In this context, this work was carried out to verify the possibility of producing ornamental sunflower (Helianthus annuus L.) fertirrigated with wastewater from fish culture and its mixtures with tap water. Two experiments were conducted in 2017 in a greenhouse at Federal Rural do University of the Semiarid, in Mossoró, RN, Brazil, according to a completely randomized design with 12 replicates. The treatments consisted of dilutions of the fish's wastewater in tap water $(0,25,50$, 75 and 100\%). Determinations of plant biomass and flower characteristics were performed. The statistical analysis of the data consisted of analysis of variance by the $\mathrm{F}$ test and regression analysis. The biomass of ornamental sunflower showed significant effect of the fish's effluent dilutions, but, in general, characteristics of flowers were not influenced. The higher values of the variables of the ornamental sunflower evaluated in the first experiment, which received fertilization, indicate that the effluent did not supply the nutritional needs of the plants. The irrigation of the ornamental sunflower can be carried out with effluent from fish farming when there is another source of nutrients for the crop to produce flowers with satisfactory characteristics.
\end{abstract}

Keywords: Helianthus anuus L., liquid effluent, floriculture, aquaculture

\section{Introduction}

The activities of floriculture and cultivation of ornamental species is labor intensive as it and can generate about eight direct jobs per hectare, which, together with the possibility of generating high annual income, between 50 000 and 100000 Brazilian Reais per hectare, makes it very attractive for small farmers. According to Leite et al. (2014), this segment produces flowers and green plants in pots, temperate and tropical cut flowers, cut foliage and plants for landscaping. The Brazilian Northeast region accounted for $9.92 \%$ of this production in 2013 , being the second largest producer in Brazil. According to Duval (2014), revenues from this market increased by $12 \%$ between 2012 and 2013, reaching 5.2 billion Brazilian Reais, while for the year 2014 growth was estimated to be between 8 and $10 \%$.

This type of activity is generally a safer destination for wastewater as a source of water and nutrients. However, the quality requirements of an effluent depend on the use to be given to the plants. According to Winrock International India (2017), wastewater should receive appropriate treatment if used for irrigation of plants intended for the pharmaceutical or cosmetics industry, so that plants do not present toxic substances. On the other hand, untreated 
or primary treated wastewater can be used in plants that are only ornamental or decorative. Therefore, water management indications should not restrict their use, but depending on their characteristics, adapting it to the type of soil and crop and the form of consumption of the product (Hespanhol, 2003; Batista et al., 2013).

An environmentally and economically viable example is the use of wastewater to meet the irrigation needs of ornamental sunflower (Helianthus annuus L.). This crop, which has an attractive inflorescence and is highly sought after for ornamentation of pots and flower arranging, is a good alternative for producers due to the ease of propagation and short cycle (Anefalos \& Guilhoto, 2003; Lopes, Martins, Tamai, Oliveira, \& Carvalho, 2009).

The emphasis on using lower quality water for crops not intended for human or animal consumption is due to the increasing scarcity of quality water resources, which is more severe in arid and semi-arid regions. This is attributed to the fact that demographic and economic growth increases the demand for water resources and the irrational use reduces their availability. In addition to the high cost of obtaining water in arid and semi-arid regions, its rational use and the employment of techniques that allow it to be used more efficiently in different human activities aims to save water of good quality. The priority for using all water reserves for human consumption in case water shortages is enforced by the Federal Law 9433 (Brazil, 1997).

In regions with water shortages the reuse of wastewater is an alternative to viabilize agriculture, which has high water consumption. In addition to mitigating water scarcity, reuse preserves the environment, as it conserves the water contained in the effluent and reduces the pollution of surface and groundwater. In addition, water and nutrient supply contributes to increased cultivated area and crop productivity (Hoek et al., 2002; Herpin et al., 2007; Condé, Homem, Almeida Neto, \& Santiago, 2012).

Fish farming or aquaculture is an important source of wastewater, which has a significant amount of nutrients and does not receive adequate final disposal. According to Medeiros, Azevedo, Marques, Sousa, and Oliveira (2013), it is technically and economically feasible to use this resource in a system of integrating fish farming with the irrigated production of several crops. Thus, the productivity increases with less use of chemical fertilizers in addition to the additional revenue from the commercialization of fish. The reuse of effluents from fish farms for irrigation avoids the waste of water and results in better utilization of available resources and reduction of water captation costs. This practice reduces the environmental impact of aquaculture/pisciculture because nutrient-rich waters are no longer dumped into rivers, as well as making possible its use without treatment (Billard \& Servrin-Reyssac, 1993).

The study is important because it associates two short cycle agricultural activities suitable for small farmers that can be developed simultaneously so that one of them benefits from the other. In this context, this work was carried out for evaluating the flower production and the development of the fertigated ornamental sunflower with fish culture effluent only or in mixtures with tap water.

\section{Material and Methods}

The experiments comprised two cycles of ornamental sunflower production and were carried out between February and October 2017 at the West Campus of the Federal Rural University of the Semiarid (UFERSA), Mossoró, RN, Brazil ( $\left.5^{\circ} 12^{\prime} 48^{\prime \prime} \mathrm{S}, 37^{\circ} 18^{\prime} 44^{\prime \prime} \mathrm{W}\right)$. The chapel type greenhouse, built in a masonry and iron structure, with North-South orientation, has arch cover with 150 micron polyethylene film with anti-ultraviolet additive and is protected on the sides with $50 \%$ black mesh.

The experimental design was completely randomized with 12 replicates. The treatments consisted of the following dilutions of fish wastewater in tap water: 0 (only tap water), 25, 50, 75, and 100\% (only effluent).

The experiments consisted of sixty 8-liter polyethylene pots that received gravel at the bottom covered with a geotextile blanket. The pots were filled with $10 \mathrm{~kg}$ of commercial granular coconut fiber substrate, GOLDEN MIX $^{\circledR} 80$.

The wastewater used for irrigation was obtained from tanks in the fishery sector of UFERSA, where Tilapia (Oreochromis niloticus L.) was produced, while the tap water was obtained from the public water supply in the municipality of Mossoró. Both were submitted to physicochemical and microbiological analyzes, following the criteria of the Standard Methods for the Examination of Water and Wastewater (Rice, Baird, \& Clesceri, 2012).

The $\mathrm{pH}$, electrical conductivity (EC) and contents of calcium $\left(\mathrm{Ca}^{2+}\right)$, magnesium $\left(\mathrm{Mg}^{2+}\right)$, chloride $\left(\mathrm{Cl}^{-}\right)$, carbonate $\left(\mathrm{CO}_{3}^{2-}\right)$, bicarbonate $\left(\mathrm{HCO}^{3-}\right)$, sodium $\left(\mathrm{Na}^{+}\right)$, potassium $\left(\mathrm{K}^{+}\right)$, iron $(\mathrm{Fe})$, manganese $(\mathrm{Mn})$, zinc $(\mathrm{Zn})$, and copper $(\mathrm{Cu})$, were determined in the Laboratory of Analysis of Soil, Water and Plant (LASAP) of UFERSA. The sodium adsorption ratio (SAR) was calculated by Equation 1 . 
Where,

$$
\mathrm{SAR}=\frac{\mathrm{Na}^{+}}{\left(\sqrt{\frac{\mathrm{Ca}^{2+}+\mathrm{Mg}^{2+}}{2}}\right)^{0.5}}
$$

$\mathrm{SAR}=$ sodium adsorption ratio, $\left(\mathrm{mmol}_{\mathrm{c}} \mathrm{L}^{-1}\right)^{0.5} ; \mathrm{Na}^{+}=$sodium content, $\mathrm{mmol}_{\mathrm{c}} \mathrm{L}^{-1} ; \mathrm{Ca}^{2+}=$ calcium content, $_{\text {mmol }}$ $\mathrm{L}^{-1} ; \mathrm{Mg}^{2+}=$ magnesium content, $\operatorname{mmol}_{\mathrm{c}} \mathrm{L}^{-1}$.

The levels of total coliforms, concentrations of total solids (ST), suspended solids (SS) and dissolved solids (SD), besides the chemical oxygen demand (COD) and biochemical oxygen demand (BOD) were determined in the Laboratory of Environmental Sanitation (LASAN).

The characteristics of the tap water and of the effluent of fish farming, respectively, were: $\mathrm{pH}-7.34$ and 7.74 ; $\mathrm{EC}-0.54$ and $3.80 \mathrm{dS} \mathrm{m}^{-1} ; \mathrm{Cl}^{-}-2.00$ and $31.84 \mathrm{mmol} \mathrm{L}^{-1} ; \mathrm{CO}_{3}{ }^{2-}-0.20$ and $3.30 \mathrm{mmol} \mathrm{L}^{-1} ; \mathrm{HCO}_{3-}-3.00$ and 3.20 $\mathrm{mmol} \mathrm{L}{ }^{-1} ; \mathrm{Na}-6.11$ and $24.93 \mathrm{mg} \mathrm{L}^{-1} ; \mathrm{K}-0.20$ and $0.90 \mathrm{mg} \mathrm{L}^{-1} ; \mathrm{Mg}-0.32$ and $23.86 \mathrm{mmol} \mathrm{L}^{-1} ; \mathrm{Ca}_{-}-0.50$ and $13.50 \mathrm{mmol} \mathrm{L}^{-1}$; RAS-9.5 and $5.80 \mathrm{mmol} \mathrm{L}^{-1}$; Hardness -41 and $1868 \mathrm{mg} \mathrm{L}^{-1}$; P-0.10 and $0.87 \mathrm{mg} \mathrm{L}^{-1}$; $\mathrm{Fe}-0.040$ and $0.43 \mathrm{mgL}^{-1} ; \mathrm{Mn}-0.012$ and $0.02 \mathrm{mg} \mathrm{L}^{-1} ; \mathrm{Zn}-0.00$ and $0.05 \mathrm{mg} \mathrm{L}^{-1} ; \mathrm{Cu}-0.00$ and $0.00 \mathrm{mg} \mathrm{L}^{-1}$; $\mathrm{Cd}-0.006$ and $0.002 \mathrm{mg} \mathrm{L}^{-1} ; \mathrm{Ni}-0.015$ and $0.031 \mathrm{mg} \mathrm{L}^{-1} ; \mathrm{Pb}-0.20$ and $0.17 \mathrm{mg} \mathrm{L}^{-1} ; \mathrm{Fe}-0.040$ and $0.43 \mathrm{mg} \mathrm{L}^{-1}$; BOD -0 and $10.00 \mathrm{mg} \mathrm{L}^{-1}$; COD -0 and $135 \mathrm{mg} \mathrm{L}^{-1}$; SS- -0 and $31.33 \mathrm{mg} \mathrm{L}^{-1}$; SD-0 and $5.63 \mathrm{mg} \mathrm{L}^{-1}$; turbidity (NTU) -2.85 and 30.9 .

The sowing of the ornamental sunflower (Helianthus annuus L.) cultivar Sol Noturno (ISLA Seeds) in trays with substrate made of coconut fiber occurred on February 6, 2017 and on August 9, 2017. Irrigation in the trays was performed daily with $100 \mathrm{~mL}$ of tap water. Fifteen days after emergence (AED) the seedlings selected according to homogeneity were transplanted, remaining one plant per pot.

Before transplantation of the seedlings, the pots were saturated with water and allowed to drain freely for 24 hours. The mass of water retained after this time was adopted as a reference for irrigation, which was performed manually whenever the substrate was observed to lose its shiny appearance, as described by Liz, Carrijo, Calbo, and Oliveira (2008). The amount of water to be manually replenished was determined by difference after random weighing of some pots.

Fertilization was carried out only in the first experiment, in which were applied $100 \mathrm{~mL}$ of solution per pot containing $1.425 \mathrm{~g}$ of potassium nitrate and $0.238 \mathrm{~g}$ of urea.

During the experiments there were no weed infestation and the control of the whitefly (Bemisia tabaci) and leafminer (Liriomyza spp.) was carried out by spraying with commercial product based on Neem oil (Azadiracta indica).

For the evaluation of dry mass of shoot (DMS), the plants were cut close to the soil and dried in a forced circulation oven at $60{ }^{\circ} \mathrm{C}$ for 72 hours. This evaluation occurred on April 28 in the first experiment and October 26 in the second experiment.

The characteristics of the flowers evaluated were: external diameter (ED) and internal diameter (ID) of the capitulum, number of petals (NP), beginning of flowering, and duration of flower after flowering (Flower longevity-FL). The diameters, internal and external, were measured using a graduated ruler, horizontally and vertically, along an imaginary line joining the two ends of the petals and passing through the center of the capitulum. The readings were applied in Equation 2. These readings and counting of the number of petals were made on the day the flower was in the R5.2 stage as referred by Schneiter and Miller (1981). For the beginning of flowering it was considered the interval between the transplant and the opening of the flower in stage R5.2 of the scale.

$$
\mathrm{ED}=\frac{\mathrm{VR}+\mathrm{HR}}{2}
$$

Where,

VR = Vertical Reading; HR = Horizontal Reading.

The data were submitted to analysis of variance by the $F$ test $(p<0.05)$. For the significant variables, linear and polynomial regression analysis was performed. The choice of the regression models for each variable was based on the significance of the regression parameters.

\section{Results and Discussion}

In the two experiments the dilution of the fish effluent had a significant effect $(p<0.01)$ on the fresh mass of shoot of the ornamental sunflower (FMS), while its effect on the dry mass of the shoot (DMS) was observed only in the 
second experiment $(\mathrm{p}<0.05)$ (Table 1). In the first experiment, which received fertilization, the means of the variables were higher than in the second experiment.

Table 1. Analysis of variance of fresh mass of shoot (FMS) and dry mass of shoot (DMS) of ornamental sunflower fertigated with pisciculture effluent in experiments 1 and 2

\begin{tabular}{llllll}
\hline & \multicolumn{3}{c}{ FMS $(\mathrm{g})$} & \multicolumn{2}{c}{ DMS $(\mathrm{g})$} \\
\cline { 2 - 3 } \cline { 5 - 6 } & 1 & 2 & & \multicolumn{1}{c}{ Mean Squares } \\
\hline Sources of variation & $3314.76^{* *}$ & $52.67^{* *}$ & $42.38^{\text {ns }}$ & $5.40^{*}$ \\
Dilution & 437.42 & 7.34 & & 19.09 & 1.37 \\
Error & 166.66 & 31.56 & & 28.50 & 20.52 \\
Mean & 12.55 & 8.58 & & 15.33 & 5.70 \\
CV $(\%)$ & &
\end{tabular}

Note. ${ }^{* *}$ significant $(\mathrm{p}<0.01)$; ${ }^{*}$ significant $(\mathrm{p}<0.05)$; ${ }^{\text {ns }}$ not significant; $\mathrm{CV}$ : coefficient of variation.

The fresh mass of shoot of the ornamental sunflower in the first experiment decreased in a quadratic manner (34\%) with the increase of the dilution of the fish effluent between the application of only water and the use of only effluent (Figure 1a). This is attributed to the increased electrical conductivity of the irrigation water, reducing the accumulation of biomass of the plants (Silva et al., 2009). The osmotic effect of the effluent salinity causes a decrease in the availability of water, while the higher energy expenditure of the plants to absorb water affects their growth. In the second experiment, the FMS had a linear increase of $32 \%$ when dilution of the fish effluent increased between the use of only water and the use of only effluent (Figure 1b).

The dry mass of shoot of the sunflower was influenced only in the second experiment by the dilution of pisciculture effluent. The DMS increased in a quadratic way (14\%) when the dilution of fish effluent increased between the use of only water and the use of only effluent (Figure 1c). The increase in biomass with increased effluent dilution indicates that in a nutrient deficiency situation, the nutrients added by the effluent overturned the harmful effect of salinity.
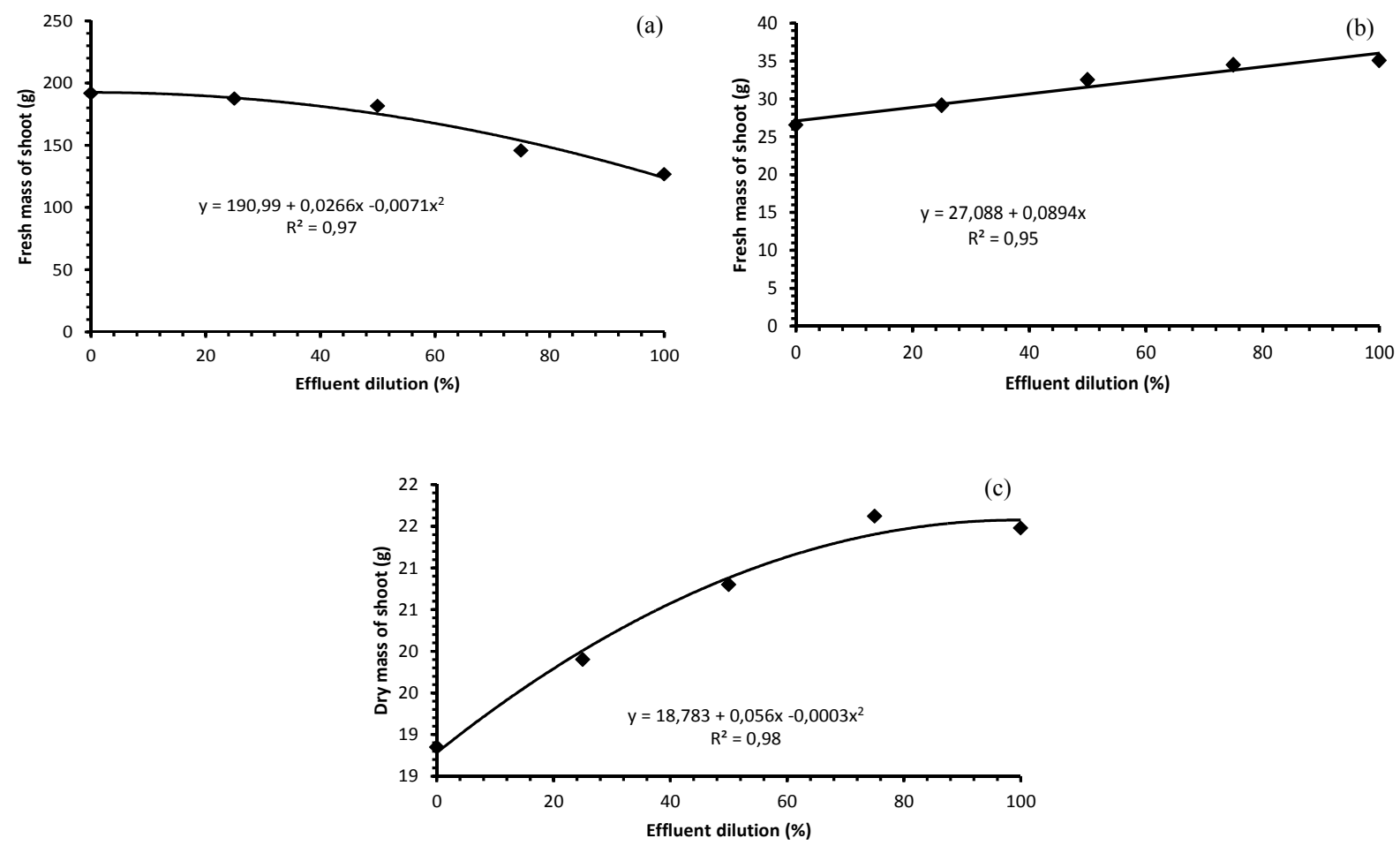

Figure 1. Fresh mass of shoot of the ornamental sunflower in the first (a) and second experiment (b) and dry mass of shoot in the second experiment (c) as a function of the dilution of the effluent mixed with tap water 
The use of wastewater in irrigation provided higher growth for all ornamental sunflower genotypes studied by Andrade, Gheyi, Nobre, Dias, and Nascimento (2012a), including the Sol Noturno. The authors obtained FMS of $28.90 \mathrm{~g}$ when they used tap water and of $134.66 \mathrm{~g}$ when used wastewater, whereas in our first experiment we obtained $167 \mathrm{~g}$ and $32 \mathrm{~g}$ in the second experiment. The same authors obtained DMS of 2.13 and $13.89 \mathrm{~g}$, inferior to the $28 \mathrm{~g}$ of our first experiment and $20 \mathrm{~g}$ of our second experiment. In the case of the cultivar Sunbright, studied by Neves, Buzetti, Castilho, and Boaro (2005), the FMS obtained was higher when the cultivation occurred in two different substrates (49 and $45 \mathrm{~g}$ ) than in soil (15 g). The values obtained in substrate by the authors were much higher than those obtained in the two experiments of our work.

The mean values of FMS and DMS obtained in our two experiments, with the cultivar Sol Noturno, were higher than those obtained by Souza, Nobre, Gheyi, Dias, and Soares (2010) with the ornamental sunflower cv. EMBRAPA BRS Oasis, with the exception of FMS in the second experiment. These authors observed that, in relation to the application of tap water, the dry mass of sunflower increased with the use of wastewater, which was the most important factor for the development of plants, even when compared with chemical fertilization and application of humus. The means obtained by them were $110 \mathrm{~g}$ of FMS when using wastewater and $35 \mathrm{~g}$ when using tap water, while wastewater plus chemical fertilization obtained $90 \mathrm{~g}$ and tap water plus chemical fertilization obtained $35 \mathrm{~g}$. As for DMS, the same treatments had means around 16, 7, 12 and $6 \mathrm{~g}$.

An explanation for the differences observed between the first and the second experiment of our work can be inferred from the work of Andrade et al. (2015), whose results of biomass of the ornamental sunflower cv. Sol Noturno indicated significant effect of organic fertilization, but not significant for the use of wastewater, that is, fertilization was more important. According to the authors, despite the nitrogen available in the wastewater used in the irrigation, it was not enough to promote a significant increase in the biomass. The authors point out that the use of wastewater combined with manure doses may have overturned the positive effect of wastewater under plant growth.

The possible negative effects of salinity of the residual water on the biomass of the ornamental sunflower were commented by Silva et al. (2009), for whom the increase of the concentration of salts in the soil tends to reduce the water consumption of the plants. The great adaptability of the sunflower causes its leaf expansion to be adjusted according to the availability of water, maintaining the appropriate turgor pressure in the cells walls. However, if there is excessive salinity, the plants have difficulty in adjusting the osmotic potential inside the cells and its growth is reduced. The good availability of water and nutrients in the plants receiving non-saline water allows for higher and more uniform distribution of photosynthetic material to the leaves and other parts of the plant. According to Travassos, Soares, Gheyi, Dias, and Nobre (2011) one of the most accepted explanation for growth inhibition due to salinity is that the reduction in dry biomass reflects a metabolic cost because the energy required for growth is diverted to adaptation to stress.

The results of the analysis of variance show that the effluent dilution had a significant effect $(p<0.05)$ only on the internal diameter of the capitulum of ornamental sunflower in the second experiment (Table 2). In a different way, Alves, Rebouças, Ferreira Neto, Batista, and Di Souza (2014) observed better characteristics for floriculture purposes of ornamental sunflower plants irrigated with waste water than those irrigated with tap water. In this sense, Andrade et al. (2014) recommend the use of wastewater from domestic sewage for ornamental sunflower irrigation, due to having benefited the quality of flowers of cultivars such as the Sol Noturno. 
Table 2. Analysis of the variance of flower characteristics of the ornamental sunflower irrigated with pisciculture effluent

\begin{tabular}{lllcl}
\hline & \multicolumn{3}{c}{ First experiment } \\
\cline { 2 - 5 } & $\mathrm{ED}(\mathrm{cm})$ & ID $(\mathrm{cm})$ & NP & FL (day) \\
\hline Source of variation & $0.14^{\mathrm{ns}}$ & $0.01^{\mathrm{ns}}$ & $16.10^{\mathrm{ns}}$ & $1.29^{\mathrm{ns}}$ \\
Dilution & 0.66 & 0.35 & 8.84 & 1.77 \\
Error & 12.20 & 5.90 & 29.59 & 9.38 \\
Mean & 6.67 & 10.01 & 10.05 & 14.16 \\
CV $(\%)$ & \multicolumn{4}{c}{ Second experiment } \\
\hline & & & Mean squares \\
Source of variation & $0.69^{\mathrm{ns}}$ & $0.52^{*}$ & $10.11^{\mathrm{ns}}$ & $1.48^{\mathrm{ns}}$ \\
Dilution & 0.63 & 0.16 & 11.14 & 0.89 \\
Error & 6.38 & 2.00 & 29.07 & 7.87 \\
Mean & 12.41 & 19.76 & 11.48 & 11.96 \\
CV $(\%)$ & & &
\end{tabular}

Note. ${ }^{*}$ significant $(\mathrm{p}<0.05) ;{ }^{\text {ns }}$ not significant; EDE: external diameter; ID: internal diameter; NP: number of petals; FL: flower longevity.

The values of the flower characteristics were much higher in the first experiment, which was fertilized, except for the number of petals. This characteristic, along with the external diameter of the chapter indicate the commercial value of the ornamental sunflower, according to Travassos et al. (2011). Although the production of flowers and sizes of flower and of the stem of ornamental sunflower are genetically defined, the highest values obtained in the first experiment can be explained by the influence of mineral nutrition (Neves et al., 2005).

The reduction in the values of flower characteristics of ornamental sunflower from one experiment to another can also be attributed to effluent salinity and lower nutrient availability. According to Silva et al. (2009), good availability of water and nutrients of plants that received non-saline water promoted a higher and more uniform distribution of the photosynthetic material to the leaves and flowers.

The internal diameter of the capitulum showed a crescent quadratic effect in the second experiment, with a $70 \%$ increase between the use of only water and the application of only effluent (Figure 2). This increase can be attributed to nutrient supply by the effluent, which increased with increasing dilution of effluent in relation to the tap water, as was also emphasized by Andrade, Gheyi, Nobre, Dias, and Nascimento (2012b).

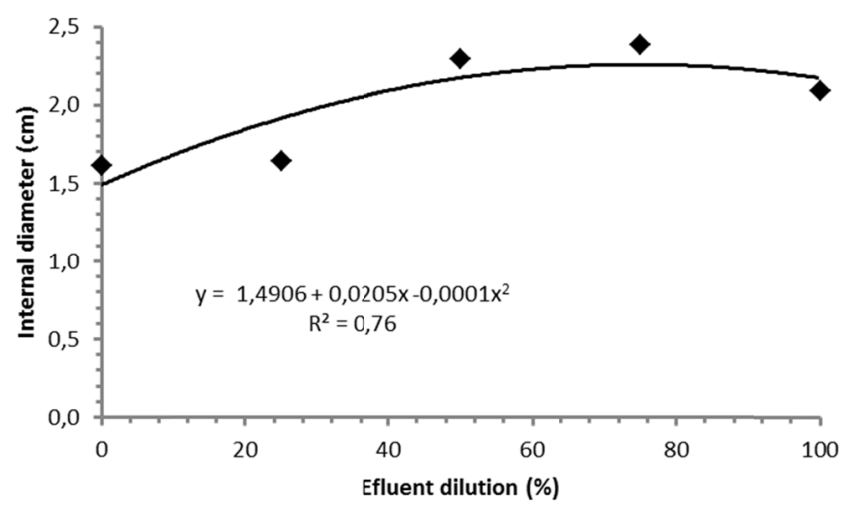

Figure 2. Internal diameter of the ornamental sunflower capitulum in the second experiment as a function of dilution of effluent in mixture with sap water

In a study by Maciel, Soares, Gheyi, Rezende, and Oliveira (2012) the ID of the cultivar Sol Noturno was not influenced by the salinity of the irrigation water, as occurred in the second experiment of the present study, in which the increase of the effluent dilution, with consequent increase of the salinity, was not a problem for the increase of the ID. The authors cited an average ID of $6.6 \mathrm{~cm}$, slightly higher than the value obtained in our first experiment $(5.9 \mathrm{~cm})$ and much higher than the value obtained in our second experiment $(2.0 \mathrm{~cm})$. The fact that they 
used nutrient solution for the production evidences that in our experiment the wastewater did not provide the necessary nutrients.

On the other hand, Andrade et al. (2012b), testing ornamental sunflower cultivars, including the Sol Noturno, obtained ID of $4.31 \mathrm{~cm}$ when using wastewater, a value inferior to that obtained in our first experiment. They obtained $2.46 \mathrm{~cm}$ using tap water, a value little higher than that obtained in our second experiment. Similarly, Souza et al. (2010) obtained an increase in the ID of the ornamental sunflower EMBRAPA BRS Oasis, from 1.97 $\mathrm{cm}$ using tap water, to $4.13 \mathrm{~cm}$ using wastewater.

The mean external diameters obtained were 12.20 and $6.38 \mathrm{~cm}$ in the first and second experiments, respectively. The diameter of the inflorescence is, along with the height of the plants, a variable that indicates the commercial value of the ornamental sunflower plant, according to Neves et al. (2005), who obtained averages of 15.1; 14.2 and $8.6 \mathrm{~cm}$, respectively when tested the substrates gravel and silica, or cultivated in the soil. In a study by Travassos et al. (2011) with the cultivar EMBRAPA 122-V2000, the ED decreased from 17.5 to $14.3 \mathrm{~cm}$ with increasing salinity of the irrigation water. Although these values are higher than those obtained in our two experiments, which may be due to the different cultivar, they are within commercial standards of 10 to $15 \mathrm{~cm}$, according to Sakata Seed Corporation (2003). Therefore, only in our first experiment adequate values of ED were obtained.

The number of petals in the two experiments performed, which was around 29 petals, was not influenced by the dilution of effluent in the irrigation water. Similarly, Andrade et al. (2014), also with the cultivar Sol Noturno, did not observe difference in NP when they used wastewater from treated domestic sewage or tap water, but they observed influence of the dose of bovine manure applied, obtaining a maximum of 30.6 petals in the dose of manure around $15 \%$ of the soil mass. The average number of petals verified for the cultivar Sol Noturno by Santos Júnior, Gheyi, Cavalcante, Dias, and Medeiros (2016) was 27 petals.

The cultivar Sol Noturno, in the study of Andrade et al. (2012a) presented an average of 29.83 petals, similar to that obtained in our two experiments. These authors observed that this cultivar presented higher NP than the other cultivars tested and that this number varied between 18.29 and 30.50 according to the irrigation was done with tap water or wastewater of treated domestic sewage. The explanation would be the additional supply of nutrients by the wastewater, especially micronutrients. On the other hand, our results were superior to those obtained by Travassos et al. (2011) with the cultivar EMBRAPA 122-V2000, which NP was reduced due to the increase of the salinity of the irrigation water, from 27.8 petals with non-saline water to 17.5 petals for the water with the highest salinity. In this aspect, our results indicate that the NP of Sol Noturno was not influenced by the increase of the salinity caused by the increase of the dilution of the effluent nor by the lower nutrient supply in the second experiment. This is confirmed by Santos Júnior et al. (2016) who did not observe effect of salinity of the nutrient solution up to the level of $9 \mathrm{dS} \mathrm{m}^{-1}$ on NP and on the longevity of the flowers of the cultivars Sol Noturno and Anão-de-Jardim.

The increase of the dimensions of the flowers in experiments with wastewater is attributed by Alves et al. (2014) to the greater availability of nutrients, mainly of nitrogen. However, the authors consider that a large amount of $\mathrm{N}$ is not necessary to obtain adequate sized capitulum. Thus, the similarity of NP averages between the two experiments may be due to an excess of $\mathrm{N}$ in the first experiment, due to the fertilization performed, whereas in the second experiment the effluent supply would have been sufficient, as was also observed by Andrade et al. (2012b).

The longevity of the flowers after flowering was higher in the first experiment (14.16 days) than in the second experiment (11.96 days). These results are superior to those obtained by Andrade et al. (2012a), with the same cultivar, which stood out for its post-cut shelf life (9.08 days), approximately 2.5 days longer than the other genotypes tested. According to these authors, until 10 days after harvest the flowers for cutting are still considered commercially accepted.

In this regard, Curti, Martin, Ferronato, and Benin (2012) tested ornamental sunflower cultivars under normal growing conditions and observed an average longevity of five days, during which the flower stems of the sunflower remained with good quality for commercialization. Beyond this time, the authors consider that the flower stems could be maintained in floral arrangements for another three to five days. The best performance in height of plants of ornamental sunflower correlates with the post-harvest longevity, according to Souza et al. (2010). According to these authors, flowers with stems of $70 \mathrm{~cm}$ lasted 9 days on the shelf and those with $50 \mathrm{~cm}$ height lasted 5 days. An important conclusion of Santos Júnior et al. (2016) is that the differences in NP and flower longevity are also due to the ornamental sunflower cultivars used. 


\section{Conclusion}

The ornamental sunflower biomass presented a significant effect of the dilutions of the fish effluent, while in general, the characteristics of the flowers were not influenced.

The highest values of the ornamental sunflower variables obtained in the first experiment, which was fertilized, indicate that the fish effluent did not provide the necessary nutrients to the plants.

The irrigation of the ornamental sunflower can be carried out with effluent from fish farming when there is another source of nutrients for the crop to produce flowers with satisfactory characteristics.

\section{References}

Alves, S. M. C., Rebouças, J. R. L., Ferreira Neto, M., Batista, R. O., \& Di Souza, L. (2014). Fertirrigação de girassol ornamental com esgoto doméstico tratado em sistema de hidroponia. Irriga, 19(4), 714-726. https://doi.org/10.15809/irriga.2014v19n4p714

Andrade, L. A., Gheyi, H. R., Nobre, R. G., Dias, N. S., \& Nascimento, E. C. S. (2012a). Qualidade de flores de girassóis ornamentais irrigados com águas residuária e de abastecimento. Idesia, 30(2), 19-27. https://doi.org/10.4067/S0718-34292012000200003

Andrade, L. O., Gheyi, H. R., Nobre, R. G., Dias, N. S., \& Nascimento, E. C. S. (2012b). Crescimento de girassóis ornamental em sistema de produção orgânica e irrigada com água residuária tratada. Irriga, Special, 69-82.

Andrade, L. O., Gheyi, H. R., Dias, N. S., Nobre, R. G., Soares, F. A. L., \& Nascimento, E. C. S. (2014). Qualidade de flores de girassol ornamental irrigado com água residuária e doses de esterco. Revista Caatinga, 27(3), 142-149.

Andrade, L. O., Nobre, R. G., Dias, N. S., Cheyi, H. R., Soares, F. A. L., \& Nascimento, E. C. S. (2015). Morfometria de plantas de girassol ornamental e atributos químicos de um solo irrigado com água residuária e adubado com esterco. Científica, 43(3), 268-279. https://doi.org/10.15361/1984-5529.2015 v43n3p268-279

Anefalos, L. C., \& Guilhoto, J. J. M. (2003). Estrutura do mercado brasileiro de flores e plantas ornamentais. Agricultura em São Paulo, 50(2), 41-63.

Batista, R. O., Oliveira, R. A., Santos, D. B. dos, Oliveira, A. de F. M., Azevedo, C. A. V. de, \& Medeiros, S. de S. (2013). Obstrução e uniformidade de aplicação em sistemas de irrigação por gotejamento aplicando-se efluente da suinocultura. Revista Brasileira de Engenharia Agrícola e Ambiental, 17(7), 698-705. https://doi.org/10.1590/S1415-43662013000700002

Billard, R., \& Servrin-Reyssac, J. (1993). Les impacts negatifs et positifs de la pisciculture d'étang sur l'environnement. In G. Barnabé, \& P. Kestemont (Eds.), Production, Environment and Quality: Proceedings of the International Conference Bordeaux Aquaculture '92 (pp. 17-29). Bordeaux, France: European Aquaculture Society.

Brasil. (1997). Lei Federal $n^{\circ}$ 9.433, de 8 de janeiro de 1997. Brasília: Casa Civil, Presidência da República.

Condé, M. S., Homem, B. G. C., Almeida Neto, O. B. de, \& Santiago, A. M. F. (2012). Influência da aplicação de águas residuárias de criatórios de animais no solo: Atributos químicos e físicos. Revista Brasileira de Agropecuária Sustentável, 2(1), 99-106. https://doi.org/10.21206/rbas.v2i1.63

Curti, G. L., Martin, T. N., Ferronato, M. L., \& Benin, G. (2012). Girassol ornamental: Caracterização, pós-colheita e escala de senescência. Revista de Ciências Agrárias, 35(1), 240-250.

Duval, C. M. (2014). A produção de flores e a agricultura familiar. Horticultura Brasileira, 32(2). https://doi.org/10.1590/S0102-05362014000200022

Herpin, U., Gloaguen, T. V., Fonseca, A. F., Montes, C. R., Mendonca, F. C., Piveli, R. P., ... Melfi, A. J. (2007). Chemical effects on the soil plant system in a secondary treated wastewater irrigated coffee plantation-A pilot field study in Brazil. Agricultural Water Management, 89(1-2), 105-115. https://doi.org/10.10 16/j.agwat.2007.01.001

Hespanhol, I. (2003). Potencial de reúso de água no Brasil: Agricultura, indústria, município e recarga de aquíferos. In P. C. S. Mancuso, \& H. F. Santos (Eds.), Reúso de água. São Paulo: Manole. 
Hoek, W. V. D., Hassan, M. U., Ensink, J. H. J., Feenstra, S., Raschid-Sally, L., Munir, S., ... Matsuno, Y. (2002). Urban wastewater: A valuable resource for agriculture; a case study from Horoonabad, Pakistan (p. 29). Colombo: International Water Management Institute.

Leite, R. M. V. B. de C., Castro, C., Brighenti, A. M., Oliveira, A. O., Carvalho, C. G., \& Oliveira, A. C. B. (2015). Indicações para o Cultivo de Girassol nos Estados do Rio Grande do Sul, Paraná, Mato Grosso do Sul, Mato Grosso, Goiás e Roraima (p. 36). Londrina, Brasil: Embrapa Soja.

Liz, R. S., Carrijo, A. O., Calbo, A. G., \& Oliveira, C. A. S. (2008). Mini sensor Irrigas ${ }^{\circledR}$ na determinação da curva de retenção de água em substratos para hortaliças. Horticultura Brasileira, 26(4), 504-509. https://doi.org/10.1590/S0102-05362008000400016

Lopes, P. V. L., Martins, M. C., Tamai, M. A., Oliveira, A. C. B. de, \& Carvalho, C. G. P. de. (2009). Produtividade de genótipos de girassol em diferentes épocas de semeadura no oeste da Bahia (p. 4). Pelotas, Brasil: Embrapa Clima Temperado.

Maciel, M. P., Soares, T. M., Gheyi, H. R., Rezende, E. P. L., \& Oliveira, G. X. S. (2012). Produção de girassol ornamental com uso de águas salobras em sistema hidropônico NFT. Revista Brasileira de Engenharia Agricola e Ambiental, 16(2), 165-172. https://doi.org/10.1590/S1415-43662012000200006

Medeiros, D. C., Azevedo, C. M. S. B., Marques, L. F., Sousa, R. A., \& Oliveira, C. J. (2013). Qualidade de mudas de tomate em função do substrato e irrigação com efluente de piscicultura. Revista Brasileira de Agroecologia, 8(2), 170-175.

Neves, M. B., Buzetti, S., Castilho, R. M. M., \& Boaro, C. S. F. (2005). Desenvolvimento de plantas de girassol ornamental (Helianthus annuus L.) em vasos, em dois substratos com solução nutritiva e em solo. Cientifica, 33(2), 27-133.

Rice, E. W., Baird, R. B., \& Clesceri, A. D. (2012). Standard methods for the examination of water and wastewater (22th ed., p. 1496). Washington, DC: APHA, AWWA, WPCR.

Sakata Seed Corporation. (2003). Sakata's reliable seeds: Flower seed catalogue 2001-2003. Bragança Paulista, Brasil: Sakata Sementes Agroflora.

Santos Júnior, J. A., Gheyi, H. R., Cavalcante, A. R., Dias, N. S., \& Medeiros, S. S. (2016). Produção e pós-colheita de flores de girassóis sob estresse salino em hidroponia de baixo custo. Engenharia Agrícola, 36(3), 420-432. https://doi.org/10.1590/1809-4430-Eng.Agric.v36n3p420-432/2016

Schneiter, A. A., \& Miller, J. F. (1981). Description of sunflower growth stages. Crop Science, 21, 901-903. https://doi.org/10.2135/cropsci1981.0011183X002100060024x

Silva, T. G. F. S., Zolnier, S., Grossi, J. A. S., Barbosa, J. G., Moura, C. R. W., \& Muniz, M. A. (2009). Crescimento do girassol ornamental cultivado em ambiente protegido sob diferentes níveis de condutividade elétrica de fertirrigação. Revista Ceres, 56(5), 602-610.

Souza, R. M., Nobre, R. G., Gheyi, H. R., Dias, N. S., \& Soares, F. A. L. (2010). Utilização de água residuária e de adubação orgânica no cultivo do girassol. Revista Caatinga, 23(2), 125-133.

Travassos, K. D., Soares, F. A. L., Gheyi, H. R., Dias, N. S., \& Nobre, R. G. (2011). Crescimento e produção de flores de girassol irrigado com água salobra. Revista Brasileira de Agricultura Irrigada, 5(2), 123-133. https://doi.org/10.7127/rbai.v5n200036

Winrock International India. (2007). Urban wastewater: Livelihoods, health and environmental impacts in India (p. 160). Colombo: IWMI. Retrieved from http://www.iwmi.cgiar.org/assessment/files_new/research_ projects/Urban\%20Wastewater-Full_Report.pdf

\section{Copyrights}

Copyright for this article is retained by the author(s), with first publication rights granted to the journal.

This is an open-access article distributed under the terms and conditions of the Creative Commons Attribution license (http://creativecommons.org/licenses/by/4.0/). 